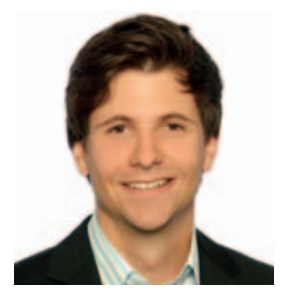

Dr. med. Marc-Andrea Bärtsch

marc-andrea.baertsch@med.uni-heidelberg.de

\title{
Neue Therapieoptionen für Patienten mit rezidiviertem Multiplem Myelom
}

\author{
Ausgewählt und kommentiert von \\ Dr. med. Marc-Andrea Bärtsch (Heidelberg)
}

Die Einführung neuer Substanzen in die Therapie des Multiplen Myeloms (MM) hat in den letzten 20 Jahren erfreulicherweise zu einer deutlichen Verlängerung des Überlebens geführt. Nichtsdestotrotz belegte eine viel zitierte Studie noch im Jahr 2012 [1] ein Gesamtüberleben von nur 9 Monaten, sobald eine Refraktärität auf die zwei Eckpfeiler der Myelomtherapie, Bortezomib und Immunmodulatoren (Lenalidomid, Thalidomid), vorlag. Seither wurden in der Medikamentenentwicklung weitere große Fortschritte erzielt, was in der Zulassung von 4 neuen Substanzen durch die European Medicines Agency (EMA) innerhalb der letzten 12 Monate gipfelte. Die Therapieoptionen für Patienten mit rezidiviertem MM haben sich dadurch innert kurzer Zeit vervielfacht. Während das neu zugelassene Carfilzomib (Kyprolis ${ }^{\circledR}$ ) in die Klasse der Proteasominhibitoren einzuordnen ist, stellen Panobinostat (Farydak ${ }^{\circledR}$ ) als Histondeacetylaseinhibitor und Elotuzumab (Emplicit ${ }^{\circledR}$ ) sowie Daratumumab (Darzalex ${ }^{\circledR}$ ) als monoklonale Antikörper Vertreter ganz neuer Medikamentenklassen in der Therapie des MM dar.

Im Folgenden gibt dieser Beitrag eine kurze Übersicht über die wichtigsten klinischen Studien, die jeweils an rezidivierten MM-Patienten durchgeführt wurden und zur Zulassung der jeweiligen Substanzen führten. Zum Abschluss wird ein Ausblick auf laufende Studien gegeben, die die zukünftige Therapielandschaft des rezidivierten MM weiter verändern werden.

Carfilzomib wurde auf Basis der Daten der Phase-III-Studie ASPIRE [2] zunächst in Kombination mit Lenalidomid und Dexamethason (KRD) zugelassen für Patienten mit mindestens einer Vortherapie. Die ASPIRE-Studie belegt für die Kombination im Vergleich zur bisherigen Standardtherapie mit Lenalidomid und Dexamethason (RD) einen Vorteil im progressionsfreien Überleben (PFS) von 26 vs. 18 Monaten. Wenig später erfolgte dann die Ausweitung der Zulassung von Carfilzomib auf eine erhöhte Dosierung in Kombination mit Dexamethason (KD); hier hatte die Phase-III-Studie ENDEAVOR [3] in einem mutigen Vergleich mit dem etablierten Vertreter der gleichen Substanzklasse, Bortezomib, einen PFS-Vorteil von 19 vs. 9 Monaten ergeben. An Nebenwirkungen sind während der Therapie mit Carfilzomib speziell Hämatotoxizität (besonders in Kombination mit Revlimid) und Auslösung bzw. Verstärkung einer Herzinsuffizienz (Häufigkeit im einstelligen Prozentbereich) sowie Hypertension zu beachten. Polyneuropathien treten während der Carfilzomibtherapie sehr viel seltener auf als während einer Bortezomibtherapie.

Panobinostat wurde zugelassen auf Basis der Phase-III-Studie PANORAMA-1 [4], die für die Kombination Panobinostat, Bortezomib und Dexamethason (FVD) im Vergleich zu Bortezomib und Dexamethason (VD) einen PFS-Vorteil von 12 vs. 8 Monaten im Gesamtkollektiv

\section{KARGER}

Fax +4976145207 14

information@karger.com www.karger.com
๑๑ 2016 S. Karger GmbH, Freiburg
Dr. med. Marc-Andrea Bärtsch

Medizinische Universitätsklinik Heidelberg

Abteilung Innere Medizin $Y$

Im Neuenheimer Feld 410, 69120 Heidelberg, Deutschland

marc-andrea.baertsch@med.uni-heidelberg.de 
belegt. In der Subgruppe der Patienten mit 2 Vortherapien inklusive Immunmodulator und Bortezomib, für die nun die Zulassung vorliegt, betrug der PFS-Vorteil sogar 12 vs. 5 Monate [5]. Interessanterweise konnte die Phase-II-Studie PANORAMA-2 [6] für FVD eine Ansprechrate von gut einem Drittel bei Patienten mit BortezomibRefraktärität nachweisen. An Nebenwirkungen sind unter Panobinostat speziell Fatigue, welche vor allem bei älteren Patienten ausgeprägt sein kann, Thrombozytopenie und Diarrhoe zu beachten. Elotuzumab als monoklonaler Anti-SLAMF7-Antikörper war in der Phase-III-Studie ELOQUENT-2 [7] in Kombination mit Lenalidomid und Dexamethason (Elo-RD) der Standardtherapie mit letzteren beiden Substanzen überlegen; der PFS Vorteil betrug 19 vs. 15 Monate. Zudem war das Intervall bis zum Beginn der nächsten Therapie nach Elo-RD um 12 Monate länger als nach RD. Diese gut verträgliche Therapie ist für Patienten mit mindestens einer Vortherapie zugelassen.

Daratumumab richtet sich gegen das Oberflächenmolekül CD38 und ist als Monotherapie auch bei stark vorbehandelten Patienten wirksam. In der Phase-II-Studie SIRIUS [8] und in einer weiteren Phase-I/II Studie [9] erreichten Patienten mit im Median 5 bzw. 4 Vortherapien bei einer Ansprechrate von 29\% bzw. 36\% ein medianes PFS von 4 bis 6 Monaten. Bei Patienten, bei denen ein Therapieansprechen zu verzeichnen war, hielt dieses in der SIRIUS-Studie im Median 7 Monate an; in der zweiten zitierten Studie waren sogar 65\% dieser Patienten nach 12 Monaten noch ohne erneuten Krankheitsprogress. Die Zulassung liegt für Patienten vor, die bereits mindestens mit einem Proteasom-Inhibitor und einem Immunmodulator vorbehandelt sind. Gemein ist beiden monoklonalen Antikörpern ein vorteilhaftes Nebenwirkungsspektrum, wobei vor allem Infusionsreaktionen bei der Erstgabe zu beachten sind; diese treten gerade bei Daratumumab sehr häufig auf, sind aber durch rasches Pausieren der Infusion sowie die Applikation antiallergischer Supportivmedikation sehr gut zu kontrollieren. Interessanterweise ist die Expression der Ziel-Antigene von Elotuzumab und Daratumumab (SLAMF7 bzw. CD38) mitnichten plasmazell- bzw. myelomzellspezifisch; gerade das Vorhandensein beider Oberflächenproteine auf verschiedenen Zelltypen des Immunsystems und die Bedeutung dieser Tatsache für die Wirksamkeit von Elotuzumab und Daratumumab sind aktuell Gegenstand intensiver Untersuchungen.

Aufgrund des vergleichsweise langen Überlebens beim MM dauert es entsprechend lange, bis aus Studien verlässliche Daten zum Overall Survival (OS) abgeleitet werden können. Zudem kann der medizinisch sinnvolle Einsatz der schließlich zugelassenen Substanzen dazu führen, dass bei den Patienten aus den jeweiligen Kontrollarmen der Studien kein signifikanter OS-Unterschied zustande kommt. Nichtsdestotrotz werden diese Daten natürlich mit Spannung erwartet.

Aktuell werden im Rahmen von Studien verschiedene Kombinationen der genannten Substanzen mit bereits zugelassenen wie auch mit in der Entwicklung befindlichen Substanzen bei Patienten mit rezidiviertem MM untersucht. Hervorzuheben sind hier die beiden laufenden Studien zur Kombination von Daratumumab mit Bortezomib bzw. Lenalidomid. Zur CASTOR-Studie, die die Wirksamkeit von Daratumumab in Kombination mit Bortezomib und
Dexamethason im Vergleich zur Standardtherapie mit letzteren beiden Substanzen untersucht, wurden kürzlich die Ergebnisse einer Zwischenauswertung [10] veröffentlicht. Hier zeigte sich ein PFS nach 12 Monaten von 61\% vs. 27\% zugunsten der Kombination mit Daratumumab. Exzellente frühe Daten liegen auch zur POLLUXStudie (Vergleich von Daratumumab, Lenalidomid und Dexamethason mit Lenalidomid und Dexamethason) vor. An der diesjährigen Jahrestagung der European Hematology Association wurde eine Reduktion des Progressionsrisikos im Daratumumab-Arm von 63\% berichtet [11]; mit einer durchschnittlichen Beobachtungszeit von 14 Monaten war das geschätzte mediane PFS im Daratumumab-Arm noch nicht erreicht, während es im Kontrollarm 18 Monate betrug. Zukünftig ist mit der Ausweitung der Zulassung von Daratumumab auf die beschriebenen Kombinationen zu rechnen. Ein weiterer beliebter Kombinationspartner im Rahmen klinischer Studien ist aktuell der Immunmodulator Pomalidomid. Hier werden vielversprechende Kombinationen mit Elotuzumab, Daratumumab, Immuncheckpoint-Inhibitoren, Histon-DeacetylaseInhibitoren und anderen Substanzen untersucht. Daneben befinden sich viele weitere zielgerichtete Substanzen in der präklinschen und klinischen Entwicklung. Nicht zuletzt sind experimentelle T-Zell-basierte immunologische Therapieansätze mit chimären Antigenrezeptoren zu erwähnen, die mittlerweile auch beim MM klinische Phase-I-Studien erreicht haben und im Stande sind, beeindruckende Remissionen herbeizuführen [12].

Die Zulassung der beschriebenen Substanzen bedeutet schon heute eine wertvolle Erweiterung der Therapieoptionen für Patienten mit rezidiviertem MM, die sich im Gesamtüberleben mit dieser nach wie vor meist nicht heilbaren Erkrankung niederschlagen wird. Neue Kombinationsmöglichkeiten sowie die konsequente Weiterentwicklung neuer Therapieansätze stimmen für die Zukunft optimistisch.

Dimopoulos MA, Moreau P, Palumbo A, et al.: Carfilzomib and dexamethasone versus bortezomib and dexamethasone for patients with relapsed or refractory multiple myeloma (ENDEAVOR): a randomised, phase 3, open-label, multicentre study. Lancet Oncol 2016;17:27-38.

Background: Bortezomib with dexamethasone is a standard treatment option for relapsed or refractory multiple myeloma. Carfilzomib with dexamethasone has shown promising activity in patients in this disease setting. The aim of this study was to compare the combination of carfilzomib and dexamethasone with bortezomib and dexamethasone in patients with relapsed or refractory multiple myeloma.

Methods: In this randomised, phase 3, open-label, multicentre study, patients with relapsed or refractory multiple myeloma who had one to three previous treatments were randomly assigned (1:1) using a blocked randomisation scheme (block size of four) to receive carfilzomib with dexamethasone (carfilzomib group) or bortezomib with dexamethasone (bortezomib group). Randomisation was stratified by previous proteasome inhibitor therapy, previous lines of treatment, International Staging System stage, and planned route of bortezomib administration if randomly assigned to bortezomib with dexamethasone. Patients received treatment until progression with carfilzomib $(20 \mathrm{mg} / \mathrm{m}(2)$ on days 1 and 2 of cycle $1 ; 56 \mathrm{mg} / \mathrm{m}(2)$ thereafter; $30 \mathrm{~min}$ intravenous infusion) and dexamethasone (20 $\mathrm{mg}$ oral or intravenous infusion) or bortezomib $(1 \times 3 \mathrm{mg} / \mathrm{m}(2)$; intravenous bolus or sub- 
cutaneous injection) and dexamethasone (20 mg oral or intravenous infusion). The primary endpoint was progression-free survival in the intention-to-treat population. All participants who received at least one dose of study drug were included in the safety analyses. The study is ongoing but not enrolling participants; results for the interim analysis of the primary endpoint are presented. The trial is registered at ClinicalTrials.gov, number NCT01568866.

Findings: Between June 20, 2012, and June 30, 2014, 929 patients were randomly assigned (464 to the carfilzomib group; 465 to the bortezomib group). Median follow-up was $11 \times 9$ months $($ IQR $9 \times 3-16 \times 1)$ in the carfilzomib group and $11 \times 1$ months $(8 \times 2-14 \times 3)$ in the bortezomib group. Median progression-free survival was $18 \times 7$ months $(95 \%$ CI $15 \times 6-$ not estimable) in the carfilzomib group versus $9 \times 4$ months $(8 \times 4-10 \times 4)$ in the bortezomib group at a preplanned interim analysis (hazard ratio [HR] $0 \times 53$ [95\% CI $0 \times 44-0 \times 65] ; \mathrm{p}<0 \times 0001)$. On-study death due to adverse events occurred in 18 (4\%) of 464 patients in the carfilzomib group and in $16(3 \%)$ of 465 patients in the bortezomib group. Serious adverse events were reported in 224 (48\%) of 463 patients in the carfilzomib group and in 162 (36\%) of 456 patients in the bortezomib group. The most frequent grade 3 or higher adverse events were anaemia (67 [14\%] of 463 patients in the carfilzomib group vs 45 [10\%] of 456 patients in the bortezomib group), hypertension (41 [9\%] vs $12[3 \%])$, thrombocytopenia (39 [8\%] vs $43[9 \%])$, and pneumonia (32 [7\%] vs $36[8 \%])$.

Interpretation: For patients with relapsed or refractory multiple myeloma, carfilzomib with dexamethasone could be considered in cases in which bortezomib with dexamethasone is a potential treatment option. Funding: Onyx Pharmaceuticals, Inc., an Amgen subsidiary.

San-Miguel JF, Hungria VT, Yoon SS, et al.: Panobinostat plus bortezomib and dexamethasone versus placebo plus bortezomib and dexamethasone in patients with relapsed or relapsed and refractory multiple myeloma: a multicentre, randomised, double-blind phase 3 trial. Lancet Oncol 2014; 15:1195-1206.

Background: Panobinostat is a potent oral pan-deacetylase inhibitor that in preclinical studies has synergistic anti-myeloma activity when combined with bortezomib and dexamethasone. We aimed to compare panobinostat, bortezomib, and dexamethasone with placebo, bortezomib, and dexamethasone in patients with relapsed or relapsed and refractory multiple myeloma.

Methods: PANORAMA1 is a multicentre, randomised, placebo-controlled, double-blind phase 3 trial of patients with relapsed or relapsed and refractory multiple myeloma who have received between one and three previous treatment regimens. Patients were randomly assigned (1:1) via an interactive web-based and voice response system, stratified by number of previous treatment lines and by previous use of bortezomib, to receive 21 day cycles of placebo or panobinostat (20 mg; on days $1,3,5,8,10,12$, orally), both in combination with bortezomib $(1 \times 3 \mathrm{mg} / \mathrm{m}(2)$ on days $1,4,8,11$, intravenously $)$ and dexamethasone (20 mg on days $1,2,4,5,8,9,11,12$, orally). Patients, physicians, and the investigators who did the data analysis were masked to treatment allocation; crossover was not permitted. The primary endpoint was progression-free survival (in accordance with modified European Group for Blood and Marrow Transplantation criteria and based on investigators' assessment) and was analysed by intention to treat. The study is ongoing, but no longer recruiting, and is registered at ClinicalTrials.gov, number NCT01023308.

Findings: 768 patients were enrolled between Jan 21, 2010, and Feb 29, 2012, with 387 randomly assigned to panobinostat, bortezomib, and dexamethasone and 381 to placebo, bortezomib, and dexamethasone. Median followup was $6 \times 47$ months (IQR $1 \times 81-13 \times 47)$ in the panobinostat group and $5 \times 59$ months $(2 \times 14-11 \times 30)$ in the placebo group. Median progressionfree survival was significantly longer in the panobinostat group than in the placebo group $(11 \times 99$ months [ $95 \%$ CI $10 \times 33-12 \times 94]$ vs $8 \times 08$ months $[7 \times 56-9 \times 23]$; hazard ratio [HR] $0 \times 63,95 \% \mathrm{CI} 0 \times 52-0 \times 76 ; \mathrm{p}<0 \times 0001$ ). Overall survival data are not yet mature, although at the time of this analysis, median overall survival was $33 \times 64$ months $(95 \%$ CI $31 \times 34-$ not estimable) for the panobinostat group and $30 \times 39$ months $(26 \times 87-$ not estimable) for the placebo group (HR $0 \times 87,95 \%$ CI $0 \times 69-1 \times 10 ; \mathrm{p}=0 \times 26$ ). The proportion of patients achieving an overall response did not differ between treatment groups $(235$ [60 $\times 7 \%, 95 \%$ CI $55 \times 7-65 \times 6]$ for panobinostat vs 208 [ $54 \times 6 \%, 49 \times 4-59 \times 7]$ for placebo; $\mathrm{p}=0 \times 09)$; however, the proportion of patients with a complete or near complete response was significantly higher in the panobinostat group than in the placebo group (107 [ $27 \times 6 \%, 95 \%$ CI $23 \times 2-32 \times 4]$ vs $60[15 \times 7 \%, 12 \times 2-19 \cdot 8] ; \mathrm{p}=0 \times 00006)$. Minimal responses were noted in $23(6 \%)$ patients in the panobinostat group and in $42(11 \%)$ in the placebo group. Median duration of response (partial response or better) was $13 \times 14$ months $(95 \%$ CI $11 \times 76-14 \times 92)$ in the panobinostat group and $10 \times 87$ months $(9 \times 23-11 \times 76)$ in the placebo group, and median time to response (partial response or better) was $1 \times 51$ months $(1 \times 41-1.64)$ in the panobinostat group and $2 \times 00$ months $(1 \times 61-2 \times 79)$ in the placebo group. Serious adverse events were reported in $228(60 \%)$ of 381 patients in the panobinostat group and 157 (42\%) of 377 patients in the placebo group. Common grade 3-4 laboratory abnormalities and adverse events (irrespective of association with study drug) included thrombocytopenia (256 [67\%] in the panobinostat group vs 118 [31\%] in the placebo group), lymphopenia (202 [53\%] vs 150 [40\%]), diarrhoea (97 [26\%] vs 30 [8\%]), asthenia or fatigue (91 [24\%] vs $45[12 \%]$ ), and peripheral neuropathy (67 [18\%] vs 55 [15\%]).

Interpretation: Our results suggest that panobinostat could be a useful addition to the treatment armamentarium for patients with relapsed or relapsed and refractory multiple myeloma. Longer follow up will be necessary to determine whether there is any effect on overall survival.

Funding: Novartis Pharmaceuticals.

\section{Lonial S, Dimopoulos M, Palumbo A, et al.: Elotuzumab} therapy for relapsed or refractory multiple myeloma. N Engl J Med 2015;373:621-631.

Background: Elotuzumab, an immunostimulatory monoclonal antibody targeting signaling lymphocytic activation molecule F7 (SLAMF7), showed activity in combination with lenalidomide and dexamethasone in a phase 1b-2 study in patients with relapsed or refractory multiple myeloma.

Methods: In this phase 3 study, we randomly assigned patients to receive either elotuzumab plus lenalidomide and dexamethasone (elotuzumab group) or lenalidomide and dexamethasone alone (control group). Coprimary end points were progression-free survival and the overall response rate. Final results for the coprimary end points are reported on the basis of a planned interim analysis of progression-free survival.

Results: Overall, 321 patients were assigned to the elotuzumab group and 325 to the control group. After a median follow-up of 24.5 months, the rate of progression-free survival at 1 year in the elotuzumab group was $68 \%$, as compared with $57 \%$ in the control group; at 2 years, the rates were $41 \%$ and $27 \%$, respectively. Median progression-free survival in the elotuzumab group was 19.4 months, versus 14.9 months in the control group (hazard ratio for progression or death in the elotuzumab group, 0.70 ; $95 \%$ confidence interval, 0.57 to $0.85 ; \mathrm{P}<0.001)$. The overall response rate in the elotuzumab group was $79 \%$, versus $66 \%$ in the control group $(\mathrm{P}<0.001)$. Common grade 3 or 4 adverse events in the two groups were lymphocytopenia, neutropenia, fatigue, and pneumonia. Infusion reactions occurred in 33 patients (10\%) in the elotuzumab group and were grade 1 or 2 in 29 patients.

Conclusions: Patients with relapsed or refractory multiple myeloma who received a combination of elotuzumab, lenalidomide, and dexamethasone had a significant relative reduction of $30 \%$ in the risk of disease progression or death. (Funded by Bristol-Myers Squibb and AbbVie Biotherapeutics; ELOQUENT-2 ClinicalTrials.gov number, NCT01239797.). 
Lokhorst HM, Plesner T, Laubach JP, et al.: Targeting CD38 with daratumumab monotherapy in multiple myeloma. N Engl J Med 2015;373:1207-1219.

Background: Multiple myeloma cells uniformly overexpress CD38. We stud-

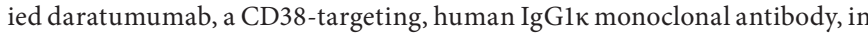
a phase 1-2 trial involving patients with relapsed myeloma or relapsed myeloma that was refractory to two or more prior lines of therapy.

Methods: In part 1, the dose-escalation phase, we administered daratumum$\mathrm{ab}$ at doses of 0.005 to $24 \mathrm{mg}$ per kilogram of body weight. In part 2, the doseexpansion phase, 30 patients received $8 \mathrm{mg}$ per kilogram of daratumumab and 42 received $16 \mathrm{mg}$ per kilogram, administered once weekly (8 doses), twice monthly ( 8 doses), and monthly for up to 24 months. End points included safety, efficacy, and pharmacokinetics.

Results: No maximum tolerated dose was identified in part 1 . In part 2, the median time since diagnosis was 5.7 years. Patients had received a median of four prior treatments; $79 \%$ of the patients had disease that was refractory to the last therapy received (64\% had disease refractory to proteasome inhibitors and immunomodulatory drugs and $64 \%$ had disease refractory to bortezomib and lenalidomide), and $76 \%$ had received autologous stem-cell transplants. Infusion-related reactions in part 2 were mild (71\% of patients had an event of any grade, and $1 \%$ had an event of grade 3 ), with no dose-dependent adverse events. The most common adverse events of grade 3 or 4 (in $\geq 5 \%$ of patients) were pneumonia and thrombocytopenia. The overall response rate was $36 \%$ in the cohort that received $16 \mathrm{mg}$ per kilogram (15 patients had a partial response or better, including 2 with a complete response and 2 with a very good partial response) and $10 \%$ in the cohort that received $8 \mathrm{mg}$ per kilogram ( 3 had a partial response). In the cohort that received $16 \mathrm{mg}$ per kilogram, the median progression-free survival was 5.6 months ( $95 \%$ confidence interval [CI], 4.2 to 8.1 ), and $65 \%$ (95\% CI, 28 to 86 ) of the patients who had a response did not have progression at 12 months.

Conclusions: Daratumumab monotherapy had a favorable safety profile and encouraging efficacy in patients with heavily pretreated and refractory myeloma. (Funded by Janssen Research and Development and Genmab; ClinicalTrials.gov number, NCT00574288.).

\section{Referenzen}

1 Kumar SK, Lee JH, Lahuerta JJ, et al.: Risk of progression and survival in multiple myeloma relapsing after therapy with IMiDs and bortezomib: a multicenter international myeloma working group study. Leukemia 2012;26: 149-57.

2 Stewart, AK, Rajkumar SV, Dimopoulos MA, et al.: Carfilzomib, lenalidomide, and dexamethasone for relapsed multiple myeloma. $\mathrm{N}$ Engl J Med 2015;372:142-152.

3 Dimopoulos MA, Moreau P, Palumbo A, et al.: Carfilzomib and dexamethasone (Kd) vs bortezomib and dexamethasone $(\mathrm{Vd})$ in patients (pts) with relapsed multiple myeloma (RMM): results from the phase III study ENDEAVOR. J Clin Oncol 2015;33(suppl):abstr 8509.

4 San-Miguel JF, Hungria VT, Yoon SS, et al.: Panobinostat plus bortezomib and dexamethasone versus placebo plus bortezomib and dexamethasone in patients with relapsed or relapsed and refractory multiple myeloma: a multicentre, randomised, double-blind phase 3 trial. Lancet Oncol 2014;15:1195-1206.
5 Richardson PG, Hungria VT, Yoon SS, et al.: Panobinostat plus bortezomib and dexamethasone in previously treated multiple myeloma: outcomes by prior treatment. Blood 2016;127: 713-721.

6 Richardson PG, Schlossman RL, Alsina M, et al.: PANORAMA 2: panobinostat in combination with bortezomib and dexamethasone in patients with relapsed and bortezomib-refractory myeloma. Blood 2013;122:2331-2337.

7 Lonial S, Dimopoulos M, Palumbo A, et al.: Elotuzumab therapy for relapsed or refractory multiple myeloma. N Engl J Med 2015;373: 621-631.

8 Lonial S, Weiss BM, Usmani SZ, et al.: Daratumumab monotherapy in patients with treatment-refractory multiple myeloma (SIRIUS): an open-label, randomised, phase 2 trial. Lancet 2016;387:1551-1560.

9 Lokhorst HM, Plesner T, Laubach JP, et al.: Targeting CD38 with daratumumab monotherapy in multiple myeloma. N Engl J Med 2015;373:1207-1219.
10 Palumbo A, Chanan-Khan A, Weisel K, et al.: Daratumumab, bortezomib, and dexamethasone for multiple myeloma. N Engl J Med 2016;375:754-766.

11 Dimopoulos MA, Oriol A, Nahi H, et al.: An open-label, randomised phase 3 study of daratumumab, lenalidomide, and dexamethasone (DRD) versus lenalidomide and dexamethasone (RD) in relapsed or refractory multiple myeloma (RRMM): POLLUX. EHA21 2016; abstract:LB2238.

12 Ali SA, Shi V, Maric I, et al.: T cells expressing an anti-B-cell-maturation-antigen chimeric antigen receptor cause remissions of multiple myeloma. Blood 2016;DOI doi:10.1182/ blood-2016-04-711903. 